\title{
Automobile Media Discourse: Verbal Media Presentation of the Electric Cars
}

\author{
Marina R. Zheltukhina ${ }^{\text {* }}$ \\ (iD) 0000-0001-7680-4003 SC 56669701900 A-7301-2015
}

\section{Gennady G. Slyshkin 2}

(iD) 0000-0001-8121-0250 SC 57191286505 G-1470-2014

\section{Conchita García Caselles ${ }^{3}$}

(iD) 0000-0002-9992-1760 SC 57196391426

Natalia V. Dubinina ${ }^{3}$

(D) 0000-0002-9137-7334 SC 57194497859

\section{Liudmila A. Borbotko 4}

(iD) 0000-0002-3500-9764 SC 57191967298

\section{Anna Yu. Shirokikh 5}

(iD) 0000-0002-5837-8941 SC 57200041371

\section{Helen V. Sausheva ${ }^{6}$ \\ (D) 0000-0002-7744-9071}

\footnotetext{
${ }^{1}$ Institute of Foreign Languages, Volgograd State Socio-Pedagogical University, Volgograd, RUSSIA

2 Law Institute, Russian University of Transport, Moscow, RUSSIA

${ }^{3}$ Faculty of Philology, Peoples' Friendship University of Russia (RUDN University), Moscow, RUSSIA

${ }^{4}$ Institute of Foreign Languages, Moscow City University, Moscow, RUSSIA

${ }^{5}$ Department of Language Studies, Financial University under the Government of the RF, Moscow, RUSSIA

${ }^{6}$ Faculty of Foreign Languages, Military University of the Ministry of Defense of the Russian Federation, Moscow, RUSSIA

*Corresponding author: zzmr@mail.ru
}

Citation: Zheltukhina, M. R., Slyshkin, G. G., Caselles, C. G., Dubinina, N. V., Borbotko, L. A., Shirokikh, A. Yu., \& Sausheva, H. V. (2020). Automobile Media Discourse: Verbal Media Presentation of the Electric Cars. Online Journal of Communication and Media Technologies, 10(3), e202012. https://doi.org/10.29333/ojcmt/7933

\section{ARTICLE INFO}

Received: 20 Nov 2019

Accepted: 8 Mar 2020

\section{ABSTRACT}

The article is devoted to a research of automobile media discourse. In the article lexical features of the English-speaking presentations of electric vehicles in mass media are distinguished. The concept "electric car / vehicle" is defined and the main ways of development of electric vehicles are considered. In the article advantages and shortcomings of electric cars in comparison with internal combustion engine vehicles in media presentations are disclosed. Structural and semantic features of the lexical presentation of electric vehicles in English-language media are revealed.

The article demonstrates that the main lexical semantic, stylistic and grammatical features help the addresser in the media presentations of electrical cars to inform the addressee about goods, to form the positive image of the electric vehicles at the buyer and to induce to buy the electric car. The research contributes to the development of psycholinguistics, media linguistics, cultural linguistics, discourse theory and influence theory, automobile media linguistics on the example of verbal media presentations of electric cars / vehicals in English-speaking countries.

Keywords: electric cars / vehicles, media discourse, automobile media discourse, media advertising, verbal presentation, promotion, lexical features, structural and semantic features, English-language media

Copyright $\odot \mathbf{2 0 2 0}$ by authors; licensee OJCMT. This article is an open access article distributed under the terms and conditions of the Creative Commons Attribution License (http://creativecommons.org/licenses/by/4.0/). 


\section{INTRODUCTION}

The end of the 20th century and the beginning of the 21 st century are represented transition to total electrification of mankind which basis can be considered the automobile sphere as one of quickly developing in the world (Svetlana, 2014) though the most part of discoveries in the sphere of electric motors for cars was made at the end of the 19th - the beginning of the 20th centuries. The mankind tries to pass to the methods and means of operation of cars which were more sparing for the environment long ago. However, to this day it is considered that entry of electric vehicles into the international market not only will complicate work of designers of these projects, but also will lead to considerable reduction of financial flows in an automobile and oil-extracting industry system.

It can be stated that electric cars are the "technology of choice for eco-friendly car buyers" (Electric Cars: What They Are and How They Work, 2019). The electric cars have no emissions tied to their operation. They can be powered with clean, renewable energy. Even when charged with power from nonrenewable sources, the inherent fuel efficiency of electric motors versus internal combustion engines means they release less carbon per mile (when similar vehicles are compared) (Electric Cars: What They Are and How They Work, 2019). The advantages of electric vehicles are actively discussed in the modern mass media: in media presentations and media publications in newspapers, magazines, on television and in the Internet.

The purpose of this work is the identification of lexical features of the English-speaking presentations of electric vehicles in mass media.

For achievement of our purpose it is necessary to solve the following problems:

- to define the concept "electric car" and to consider ways of development of electric vehicles;

- to disclose advantages and shortcomings of electric vehicles in comparison with internal combustion engine vehicles in media presentations;

- to reveal structural and semantic features of the lexical presentation of electric vehicles in Englishlanguage media.

\section{LITERATURE REVIEW}

The set of researches is devoted to problems of effective influence in a media discourse, creation of media presentations, producing media advertising for rendering successful influence on the addressee, semiotics of media advertising, verbal promotion of goods and services through media (Boeva-Omelechko et al., 2019; Dijk van, 1988, 1997; Gishkaeva et al., 2018; Grimak, 2001; Harvey, 2011; Jamieson \& Campbell, 1997; Lakoff \& Johnson, 1980; Langacker, 1991; Morris, 1971; Orekhovskaya et al., 2019; Rein, 1982; Shirokikh, 2018; Stanton et al., 1991; Sukhareva \& Karnaukhova, 1998; Tameryan et al., 2019; Tezer et al., 2019; Ukhova \& Marycheva, 2012; Wierzbicka, 1991, 1992; Zheltukhina \& Malygina, 2019; Zheltukhina et al., 2019, etc.). The presentation of goods is a meeting in the correspondence or internal look of the seller and the buyer for the purpose of representation of goods, its advantages and shortcomings, benefits which will be got by the potential buyer (Rules of holding presentation of goods, 2019).

The presentation is a link between search of goods and the final decision on acquisition of a concrete exemplar. The presentation of goods can take place full-time and part-time. The first represents a meeting of the producer of goods, his representatives and potential buyers with the purpose to obtain more information, on the one hand, and to provide goods in the best light, on the other hand. Part-time goods presentation most often is associated with creation of the specialized website where all information on innovations, improvements of concrete goods, actions which are carried out with it, preferential offers which extend to it will be published. The website is one of the most successful forms of the media presentation, according to us as it has a number of advantages which are unattainable in other types and forms. Advantages of creation of the website to the goods media presentation include:

bigger volume of qualitative information on goods (unlike internal meetings where a main objective is representation of goods in the best possible light, the websites are focused on representation fuller and as a result qualitative information on goods; 
- existence of reviews of the chosen goods: the potential buyer can see the responses tab which in a consequence of the huge competition of producers is present at any website;

- significant increase in potential audience: full-time of the presentation has territorial, temporary and other restrictions for potential buyers;

- removal of time frames: the potential buyer has an opportunity, unlimited on time, to study characteristics of the chosen goods, its pluses and minuses.

It is possible to say that the thematic websites are the most successful form of the presentation of goods. For this reason, this form of the presentation was chosen by us for detailed study and allocation of the brightest features of the lexical presentation of electric vehicles in automobile media discourse.

To carry out the analysis of the presentations of each of three leaders of the market of electric vehicles on existence of certain lexical features, it was necessary to collect originally information on what lexicon is applied most often by producers of electric vehicles in their media presentations (Tarlanov, 1995, p. 98).

As the sphere of electric vehicles gained rapid development rather recently, the basis of our work will be formed by the topical vocabularies including the lexical field of electric vehicles and cars in general (Macmillan English dictionary for advanced learners, 2002; Magnuson, 2001; Nym, 2019; Oxford Advanced Learner's Dictionary of Current English, 1987; Phythian, 1984; Svetlana, 2014; The electric vehicle, 2019; Wierzbicka, 1972, etc.). In addition, in our work WooordHunt online service (2019) is used and also excerpts from articles of researchers of this sphere. To provide information on each concrete model of the electric vehicle, a number of the most often used terms is applied (Shaumyan, 1965, p. 71-78). First of all, the word "electric vehicle" has many options among most of which often occur: "electric vehicle", "electric car" and "electromobile" (Akhmanova, 1977, p. 176).

The most widespread of them: Convertible, Coupe, Crossover Utility Vehicle (CUV), Estate, Hatchback, Limousine, Lorry" (BrE), truck (AmE), People carrier (minivan) / Multi-purpose vehicles" (MPVs), Pickup, Roadster, Sedan, Sport Utility Vehicle" (SUV), Van.

It should be noted that in verbal media presentations of electric vehicles the necessary terms from the sphere of traffic of cars realizing logic of a reasoning are significant: usually we go on road or route, adhering to lane and following the defined lane marking.

Further primary description of the main characteristics of electric vehicles follows. As a rule, the most popular of them are expressed by nouns or nouns + adjective, for example, acceleration, aerodynamics, transmission, driving gear, body style.

The important place in the presentation is also taken by the car's exterior (Wierzbicka, 1972, p. 48-69): aerial, back door, backup lights, body, bonnet (BrE), hood (AmE), boot (BrE), trunk (AmE), brake lights, stop lights, bulbs, bumper, door handle, exhaust pipe, tail pipe, fog lights, front door, front wheel, grill, headlights, high beam, hubcap, indicator, turn signal, blinker (informal), lens, low beam, moonroof, parking lights, rear wheel, rear window, roof, roof rack, side lights, side window, sunroof, tail lights, tailgate, tyre (BrE), tire (AmE), windscreen I windshield, windscreen wiper, wing (BrE), fender (AmE), wing / side mirror.

For understanding of practical value of the electric vehicle it is necessary to specify features of the internal structure of the electric vehicle, i.e. the car's content in the presentation (Wierzbicka, 1992, p. 87-101). Further are given the most often used from them: accumulator, alternator, brake pad, car alarm, carburettor (BrE), carburetor (AmE), chassis, coolant, cooling system, crankshaft, cylinder, cylinder block, dipstick, electrical system, engine, fan, fasteners, filter, fuse, ignition, starter, suspension, window roller.

For assessment of a security system (safety) of the electric vehicle such adjectives as are used: save like reliable, secure like guaranteed, innoxious like harmless (Langacker, 1991, p. 376).

The description of an interior of the electric vehicle (interior), as a rule, contains the following epithets: laconic, functional, symbolical, compact, wanted (Rein, 1982, p. 312).

\section{METHODOLOGY}

In our work the following research methods are used: definitional analysis, structural analysis, lexical and semantic analysis, lexical and grammatical analysis, interpretative analysis, technique of continuous sample. 
In verbal presentations of electric cars in media discourse we will pay special attention to structural and semantic features of lexicon (Tarlanov, 1995, p. 34).

For effective realization of the purpose of the project media resources of the most successful companies on production of electric vehicles were selected. 3 English-speaking media sources were investigated: websites of the companies: Tesla (TESLA, 2019), BAIC Group (BAICGROUP, 2019) and BYD (BYD, 2019). These producers are leaders in the market of electric cars, respectively contain a large number of the presentations of the creations on the websites.

At the end of 2018 the Bloomberg New Energy Finance agency published a research of the market of electric cars "Global pure-electric vehicle sales" (Electric cars: world market, 2019). Observers of the agency came to rather interesting opinion: during 2018 more than 1.3 million units of the electric transport were sold. As it is not strange, about $60 \%$ of total sales are the share of the market of China. Top three included such car makers as Tesla, Beijing Electric Vehicle (BAIC/BJEV) and BYD (Electric cars: world market, 2019).

In 2019 the situation changed a little. Tesla remained the largest producer of electric vehicles. Afterwards the Chinese brand of BYD was located, and top three closed BMW (Zhang, Turner, 2019).

To understand structure of the electric cars market it is necessary to define three most important players in this market in the 2018.

1. Tesla (before Tesla Motors) - the American company since 2003 , the producer of electric vehicles and (through the SolarCity branch) decisions for storage of electric energy. Unlike most car makers, Tesla does not sell cars through independent dealers. As a rule, Tesla salons represent only show flats, purchase is carried out directly via the website of Tesla.

2. BAIC Group (Beijing Automotive Industry Holding Co. or Beijing Automotive Group Co.) - the Chinese state holding company since 1958 uniting several automobile building and machine-building enterprises. The headquarters is located in Beijing. The main subsidiaries BAIC Group are BAIC Motor (cars), BAW (military and SUV cars), Foton Motor (trucks, buses, agricultural machinery), Changhe (minibuses and SUVs). Cooperation management enterprises of Beijing Hyundai and Beijing Benz release for the Chinese market cars of brands Hyundai and Mercedes respectively. The first mass NIO electric vehicle - the seven-seater ES8 crossover with the price from $\$ 53$ thousand that is twice cheaper than the cost of Tesla.

3. BYD (from English Build Your Dreams) - the producer of cars located in Shenzhen (China). BYD Auto is subsidiary of BYD Company Ltd which for the first time announced itself in 1995. The company promotes development model "Independent design, own brand, independent development", considering the purpose "Production of world-class qualitative cars", and the industry purpose "Creation of the national automobile brand of world class" (Electric cars: world market, 2019).

In our research more than 300 media presentations of electric vehicles of 3 companies which use various structural and semantic features of lexicon were analyzed as they make the greatest influence on mass audience (Zheltukhina \& Malygina, 2019; Zheltukhina et al., 2019).

\section{RESULTS AND DISCUSSION}

In our work we define the concept "electric cars" and consider ways of their development.

The electric car or vehicle represents the car which is powered by accumulators or other fuel elements (The electric vehicle, 2019). Unlike cars with the internal combustion engine the electric vehicles are rather economic, do not pollute the environment, have higher initial cost of purchase, however further with ease pay off.

The first electric vehicle was put into operation in 1841. In turn, the first car with the internal combustion engine appeared for the first time in 1885 by means of long and persistent work of Karl Benz (The electric vehicle, 2019). Because of insufficiently advanced system of recharge of the electric motor the petrol cars won secret fight for domination in the automobile market. This fact influenced formation of the automobile, industrial and social sphere. 
Only in 1960 interest in electric vehicles began to appear again. Actively developing environmental problems and an energy crisis which provoked the sharp growth of cost of fuel (Eric, 2016). Many people were not able to afford to use the car of internal combustion any more only because had no means to depreciation of the car, and that the most important, for payment fuels. This fact set a public response and, as a result, created the social order for creation of new, effective and eco-friendly engines which, in turn, would not lose positive characteristics of "outdated" option.

Many automobile concerns began to place bigger emphasis on development of technologies and tactics of introduction of electricity as main driving resource. This point was starting for the world system of automobile industry (Eric, 2016).

In our research advantages and shortcomings of electric vehicles in comparison with internal combustion engine vehicles in media presentations are disclosed.

Any technology, it is indisputable, has the pluses and minuses. Buying the car, the person surely pays attention to a number of important features without which understanding and assessment of a desirable product is impossible. Strangely enough, in recent years the automobile public was divided into two camps: the first actively supports implementation of new technologies, understanding that primary investments by all means lead to further payback, however, there are also those who cannot appreciate advantage of electric cars, and only focuses attention on their shortcomings. It is impossible to support any given point of view without detailed study and analysis of the main advantages and shortcomings which characterize the electric vehicle.

The analysis of the media presentations of electric vehicles shows that the companies investigated by us place emphasis on advantages of electric vehicles. The following main advantages of electric vehicles presented on the websites of the companies are established:

1) environmental friendliness: total absence of the exhaust gases which are polluting the environment and having negative effect on all living organisms;

2) low cost of operation: the electric power is many times cheaper than fuel, respectively, the total cost of operation falls approximately by 10 times;

3) high efficiency of the electric motor: $90-95 \%$, in comparison with the efficiency level of the internal combustion engine about 22-42\%;

4) lightness of design: the electric motor has the smaller weight, than the internal combustion engine one, including engines of sports cars;

5) possibility of charging from the standard socket: the only condition is existence of the special adapter for each model of the electric vehicle;

6) minimum probability of explosion at road accident;

7) reliability, durability and simplicity of driving.

Shortcomings of electric vehicles presented on the websites of the companies include the following:

1) small passing mileage: on condition of a full charge: about 200-600 km depending on model;

2) overstated electric motor cost: in a consequence of availability of expensive metals in its design;

3) operation of the electric motor is followed by high temperature (from $300^{\circ} \mathrm{C}$ );

4) long time of recharge process (from 2 to 6 hours, depending on model);

5) sedate fading of specific efficiency and, as a result, the death of the accumulator on condition of its misuse: incomplete charging, sharp changes in supply of electricity, cardinal change of a manner of driving without due adaptation of the accumulator;

6) lack of support of the utilization of accumulators from the state or producers of electric vehicles: accumulators comprise huge amount of system poisons and acids;

7) limited number of specialized charging sets out of the large cities.

It should be noted that shortcomings are most veiled by producers, taken out of context, and explicitly almost not presented. It is obvious that advantages equalize shortcomings. However, in so developing and actively walking forward world there is a possibility of elimination of the sharpest shortcomings of electric 
vehicles which constrain the most part of people choosing the vehicle. Summarizing, it is necessary to tell that the main reason which constrains mass production of electric vehicles is insufficient demand because of the high cost of the electric vehicle and a small passing mileage from one recharge. The high price is caused by the high cost of accumulators, and, as a result of their limited quantity in the automobile market. Due to this fact the last 20 years the increasing interest in cooperation of many car makers among themselves is observed. Similar collaboration leads not only to economy for auto production of each party, but also to increase the total number of technological innovations, due to a sharp improving efficiency of general activity, namely, the achievement of a synergistic effect.

It is noteworthy that in the studied media presentations the existence of electric cars is not limited only to personal use. In recent years electric cars (in such subspecies as electric trucks and electric lift trucks) are widely used at stations, in the subway, in big shops, etc. This type of transport is practical and relevant for service of the limited and loaded territory. The most important pluses in this question are the lack of exhausts and noise when using. For this reason, services industry of the population is called in the presentations considered by media as the most favorable soil for development and active introduction of the electric transport.

The methods of a research applied in work allowed to reveal structural and semantic features of the lexical presentation of electric vehicles in English-language media. In the course of the research it is established that any presentation of the electric vehicle comprises several fundamental parts. Among them (Sukhareva, 1998, p. 245): short characteristic of model, safety, performance, limit mileage, existence of the autopilot, interior, exterior, model range, advantages, possibility of the order.

Each of parts is characterized by the specific lexical features which, in turn, are designed to distinguish advantages in light, favorable to the producer, and to smooth the available shortcomings of a certain model of the electric vehicle. As it was noticed, most often the description is under construction in positive tone, there are almost no negative designs. Headlines of each part are allocated with a specific font, including color (Morris, 1971, p. 9).

During the analysis we selected the 110 most often found words which set defines semantic features of the lexical presentation of electric vehicles.

Such terms as electric vehicle, safety and performance are used on average 4-5 times more often than other words and phrases and especially allocated along with other lexical units (Wierzbicka, 1991, p. 342). Examples of use of some from these words:

"Model S sets an industry standard for performance and safety. Tes/a's all-electric powertrain delivers unparalleled performance in all weather conditions - with Dual Motor All-Wheel Drive, adaptive air suspension and ludicrous acceleration" (TESLA, 2019).

"Model $S$ is built from the ground up as an electric vehicle, with high-strength architecture and a floormounted battery pack allowing for incredible impact protection" (TESLA, 2019).

The phrase body style is used in body type value and very often replaced with reduction body.

"A lightweight body structure, battery management system and new $\mathrm{CO}_{2}$ air conditioning lower the energy consumption" (BYD 'Home from Home'..., 2020).

As it was already told, the concept "electric vehicle" is rather widespread, and as a result, can be expressed not by one and even not two, but dozens of variations (Stanton et al., 1991, p. 296). In the classical British English electric vehicle is expressed by a phrase electric vehicle, and in the American English the phrase electric car is used. However, these verbal expressions are interchanged (Lewis, 1952, p. 50-63).

It should be noted a huge number of numerals which considerably facilitate understanding of meaning of the text about electric cars and strengthen their information component thanks to argument accuracy:

"542 Means High-Performance

5: Acceleration from 0-100 km/h in less than 5 seconds

4: Electric 4-wheel drive with a response time of 0.02 seconds

2: Fuel consumption under 2L/100km" (Innovation at BYD, 2019). 
In addition, words which value is familiar to almost each language of the world for a long time internationalisms (42\%) are often used. For example,

"15-inch. A touchscreen display designed to improve over time. ... The inside of Model 3 is unlike any other car. You can use your smartphone as a key, and access all driver controls in the central 15-inch touchscreen. The allglass roof extends from front to back, creating a sense of openness from every seat" (TESLA: Model 3, 2019).

Here the phrase "touchscreen display" is used in "touch screen" value. Let's specify that when studying various media presentations all possible spelling variants of this word "touchscreen", namely "touch screen" and "touch-screen" were noticed. This trend has no concrete justification as native speakers indicate habitualness of writing of any given option for them (White, 2003, p. 267).

One more example is the word "monitoring" used in value "control", "check" which often meets at the description of electric vehicles (38\%):

"All new Tesla cars come standard with emergency braking, collision warning, blind-spot monitoring and more" (TESLA: Model Y, 2019).

In the text of the presentations the words "logistics" (19\%) and "market" (24\%) are quite frequency.

"In order to save energy, reduce emissions, and improve quality of life in cities, BYD has developed a wide range of practical and economical EV solutions. It has launched commercial vehicles that cover ten market segments: buses, coaches and taxis; logistics, construction and sanitation vehicles; and vehicles for warehousing, port, airport and mining operations" (BYD. Commercial Vehicle, 2019).

One of distinctive features of the presentation of electric cars is its fullness of abbreviations (Magnuson, 2001, p. 356). Further, the most widespread of them are given as an example: $A W D=$ "All-Wheel Drive"; $M P H=$ "Miles per hour"; OTA = "Over-the-air"; PPU = "Pay Per Use"; USG = "Ultra-strong glass"; PLC = "polymer-layered composite"; SLC = "self-leveling capabilities".

The most part of estimated lexicon in the media presentations of electric cars (TESLA, 2019; BAICGROUP, 2019; BYD, 2019) is realized by means of expression (Lakoff, 1980, p. 24-48):

- Epithets

"Model S is built from the ground up as an electric vehicle, with high-strength architecture and a floor-mounted battery pack allowing for incredible impact protection."

"Developing electric vehicles that are intelligent and connected, BYD is inaugurating a new age of automotive innovation."

"In order to save energy, reduce emissions, and improve quality of life in cities, BYD has developed a wide range of practical and economical EV solutions."

- Comparisons

"In a roof-crush test, Model 3 resisted four times its own mass, even with an all-glass roof: as the same weight as two full-grown African elephants."

"As traditional all-wheel drive systems, these two motors digitally control torque to the front and rear wheels for far better handling and traction control."

"The inside of Model 3 is unlike any other car. You can use your smartphone as a key, and access all driver controls in the central 15-inch touchscreen."

- Lexical repetitions

"Model 3 is fully electric, so you never need to visit a gas station again and again."

"The liftgate opens to a low trunk floor that makes loading and unloading easy and quick."

Besides lexicon, special attention in the media presentation of electric vehicles is paid to use of various grammatical structures, for creation of the most laconic and concretized description of the chosen model. For assessment of quality characteristics of electric cars, it is most often used

- Present Simple Tense

"Model Y provides maximum versatility - able to carry 7 passengers and their cargo." 
"The interior of Model $Y$ is simple and clean, with a 15-inch touch screen, immersive sound system and an expansive all-glass roof that creates extra headroom and provides a seamless view of the sky."

- Future Simple Tense

"Model Y will have Full Self-Driving capability, enabling automatic driving on city streets and highways pending regulatory approval, as well as the ability to come find you anywhere in a parking lot."

- Past Simple Tense

"The Tesla Model S was the 2013 World Green Car of the Year, 2013 Motor Trend Car of the Year, Automobile magazine's 2013 Car of the Year, Time Magazine's Best 25 Inventions of the Year 2012, and Consumer Reports' topscoring car in road testing."

Often in the media presentations of electric vehicles, there are more complex grammatic constructions (Algeo, 2006, p. 345), such as:

\section{- Conditional Tense}

"If you charge overnight at home, you can wake up to a full battery every morning. And when you're on the road, it's easy to plug in along the way - at any public station or with the Tesla charging network."

- Passive Voice

"Like every Tesla, Model Y is designed to be the safest vehicle in its class."

"Falcon Wing doors are equipped with sensors to monitor the proximity of surroundings, and can open in even the tightest parking spaces."

"If one motor stops working, you can safely continue to your destination with the second."

In the analyzed presentations, modal verbs (Marchand, 1960, p. 17) play a huge role in expressing evaluation:

"Model $X$ can get you anywhere you want to go - with industry-leading range and convenient charging options, all over the world."

"Your car can drive on either motor, so you never need to worry about getting stuck on the road."

\section{CONCLUSION}

As a result of a research the purpose was achieved and all tasks have been completed.

The concept "electric car or vehicle" was defined. It means the car which is powered by accumulators or other fuel elements. The ways of development of electric vehicles were considered, advantages and shortcomings of electric cars in comparison with internal combustion engine vehicles in media presentations were disclosed.

More than 110 words which are most used in the 300 presentations of electric vehicles are found and analyzed. It is established that the used lexical units perform the information and influencing functions in the presentations of electric vehicles.

It was established that in the presentations of electric cars in English-language media the addresser informs potential buyers on advantages and shortcomings of desirable goods, its value, the main characteristics and possibilities of the part-time acquaintance. The media addresser of the car companies forms the positive image at the buyer, inducing to buy goods thereby.

The main lexical semantic and stylistic (words and phrases in the thematic field "cars / electric cars", internationalisms, abbreviations, epithets, comparisons, lexical repetitions), grammatical features (nouns, adjectives, verbs, numerals; modal verbs; Present / Future / Past Simple Tenses; Conditional Tense; Passive Voice) of the presentations of electric vehicles in English-language media are revealed.

\section{ACKNOWLEDGEMENT}

The publication has been prepared with the support of the "RUDN University Program 5-100". 
The work is performed according to the Program of Development of Federal State Funded Educational Institution of Higher Education "Financial University under the Government of the Russian Federation" for 2020.

\section{REFERENCES}

Akhmanova, O. S. (1977). Linguistic terminology. Moscow: Moscow University Press.

Algeo, J. (2006). British or American English? A handbook of word and grammar patterns. Cambridge: Cambridge Univ. Press. https://doi.org/10.1017/CBO9780511607240

BAICGROUP. (2019). The official site of the BAIC Group company. Retrieved from http://www.baicgroup.com.cn/

Boeva-Omelechko, N. B., Posternyak, K. P., Zheltukhina, M. R., Ponomarenko, E. B., Talybina, E. V., Kalliopin, A. K., \& Ovsyannikova, M. N. (2019). Two Images of Russia in the British Political Mass Media Discourse of 1991 - 1993 and 2013 - 2019: Pragmastylistic Aspect. In: Online Journal of Communication and Media Technologies, 9(4), e201926. https://doi.org/10.29333/ojcmt/5952

BYD 'Home from Home' recognised at world-renowned if design awards. (2020). Retrieved from http://www.byd.com/en/news/2020-02-19/BYD-\%E2\%80\%98Home-from-Home\%E2\%80\%99recognised-at-world-renowned-iF-DESIGN-AWARDS

BYD. (2019). The official site of the BYD company. Retrieved from http://www.byd.com/en/eSeedGt.html

BYD. Commercial Vehicle. (2019). Retrieved from http://www.byd.com/en/CommercialVehicle.html

Dijk van, T. A. (1988). News as Discourse. New Jersey: Lawrence Elbbaum Assoc. Publ.

Dijk van, T. A. (1997). Discourse as Structure and Process: Discourse Studies a Multidisciplinary Introduction. London: SAGE Publication Ltd.

Electric Cars: What They Are and How They Work. (2019). Retrieved from https://www.cars.com/electric-cars/

Electric cars: world market. (2019). Retrieved from http://www.tadviser.ru/index.php/\%D0\%A1\%D1\% 82\%D0\%B0\%D1\%82\%D1\%8C\%D1\%8F:\%D0\%AD\%D0\%BB\%D0\%B5\%D0\%BA\%D1\%82\%D1\%80\%D0\%BE \%D0\%BC\%D0\%BE\%D0\%B1\%D0\%B8\%D0\%BB\%D0\%B8_(\%D0\%BC\%D0\%B8\%D1\%80\%D0\%BE\%D0\%B2\% D0\%BE\%D0\%B9_\%D1\%80\%D1\%8B\%D0\%BD\%D0\%BE\%D0\%BA)

Eric, A. (2016). Electric cars were popular 100 years ago. History repeats itself. Retrieved from https://1gai.ru/publ/516777-elektricheskie-avtomobili-byli-populyarnymi-100-let-nazad-istoriyapovtoryaetsya.html

Gishkaeva, L., Dubinina, N., Moskvicheva, S., \& Krivoshlykova, L. (2018). The Image of a Modern Woman in the Advertising Discourse: on the Material of Media Texts of Glossy Magazines in Russia. Astra Salvensis, 6, 643-649.

Grimak, L. P. (2001). Advertising Hypnosis: Anatomy of Mental Aggression Ideal Form. Advertising: Suggestion and Manipulation. The Media Focused Approach, 1, 727-742.

Harvey, S. (2011). Fashion lingo. Retrieved from http://virtuallinguist.typepad.com/the_virtual_linguist/ 2011/09/fashion-lingo.html

Innovation at BYD. (2019). Retrieved from http://www.byd.com/en/InnovationByd.html

Jamieson, K. H., \& Campbell, K. K. (1997). The Interplay of Influence: News, Advertising, Politics and Mass Media. Belmont: Wadsworth Publishing Company.

Lakoff, G., \& Johnson, M. (1980). Conceptual Metaphor in everyday language. Phylosophy, 77(8), 24-48. https://doi.org/10.2307/2025464

Langacker, R. W. (1991). Concept, Image and Symbol: The Cognitive Basis of Grammar. Berlin: Mouton de Gruyter.

Lewis, C. J. (1952). The Modes of Meaning. In: Semantics and the Philosophy of Language. Urbana: The University of Illinois Press, pp. 50-63.

Macmillan English dictionary for advanced learners. (2002). Oxford: Macmillan Education Ltd. Publisher.

Magnuson, W. (2001). English idioms: Sayings \& slang. Calgary (Alberta): Prairie house books.

Marchand, H. (1960). The Categories and Types of Present-day English Word-formation. Wiesbaden: Otto Harrassowitz.

Morris, Ch. (1971). Writings on the General Theory of Signs. The Hague, Paris: Mouton. https://doi.org/10.1515/9783110810592

Nym, S. (2019). Langformula. Car vocabulary. Retrieved from https://langformula.ru/car-vocabulary/ 
Orekhovskaya, N. A., Chistyakov, A. A., Kryukova, N. I., Krokhina, J. A., Ospennikov, Y. V., \& Makarova, E. V. (2019). Orthodoxy and modernity their contact facets in Russian society. European Journal of Science and Theology, 15(2), 67-77.

Oxford Advanced Learner's Dictionary of Current English. (1987). Oxford, New York: Oxford University Press.

Phythian, B. A. (1984). A Concise Dictionary of English Slang and Colloquialisms. London, Hodder and Stoughton.

Rein, D. P. (1982). The Language of Advertising and Merchandising in English. New York: Regent.

Rules of holding presentation of goods. (2019). Retrieved from https://memosales.ru/contentniy/prezentaciyatovara

Shaumyan, S. K. (1965). Structural linguistics. Moscow: Science.

Shirokikh, A. Yu. (2018). Glossary Compilation: Cultural Implications, Learners' Autonomy, Mnemonics, Professional Development and Motivation. Modern Journal of Language Teaching Methods, 8(12), 245-260.

Stanton, W., Etzel, M., \& Walker, B. (1991). Fundamentals of Marketing. San Francisco: McGraw-Hill Inc.

Sukhareva, O. E., \& Karnaukhova, L. A. (1998). The Language of Business. Tyumen: TSU.

Svetlana. (2014). Car's anatomy. Retrieved from https://engblog.ru/cars-anatomy

Tameryan, T. Y., Zheltukhina, M. R., Slyshkin, G. G., Zelenskaya, L. L., Ryabko, O. P., \& Bodony, M. A. (2019). Political Media Communication: Bilingual Strategies in the Pre-Election Campaign Speeches. Online Journal of Communication and Media Technologies, 9(4), e201921. https://doi.org/10.29333/ojcmt/5869

Tarlanov, Z. K. (1995). Methods and principles of the linguistic analysis. Petrozavodsk: Publishing house of the Petrozavodsk University.

TESLA. (2019). The official site of the Tes/a company. Retrieved from https://www.tesla.com

TESLA: Model 3. (2019). Retrieved from https://www.tesla.com/model3

TESLA: Model Y. (2019). Retrieved from https://www.tesla.com/modely

Tezer, M., Yildiz, E. P., Masalimova, A. R., Fatkhutdinova, A. M., Zheltukhina, M. R., \& Khairullina, E. R. (2019). Trends of Augmented Reality Applications and Research throughout the World: Meta-Analysis of Theses, Articles and Papers between 2001-2019 Years. International Journal of Emerging Technologies in Learning, 14(22), 154-174. https://doi.org/10.3991/ijet.v14i22.11768

The electric vehicle. (2019). Retrieved from http://study-english.info/vocabularycar.php

Ukhova, L. V., \& Marycheva, D. N. (2012). Advertising Names as Communication Means with the Consumer. Yaroslavl Pedagogical Bulletin, 1(3), 119-123.

White, R. G. (2003). Words and their uses, past and present. A study of the English language American English, 17811921. Vol. 3. L., NY: Routledge.

Wierzbicka, A. (1972). Semantic Primitives. Frankfurt: Athenäum-Verl.

Wierzbicka, A. (1991). Cross-Cultural Pragmatics: The Semantics of Human Interaction. Berlin, New York: Mouton de Gruyter.

Wierzbicka, A. (1992). Semantics, Culture and Cognition. Universal Human Concepts in Culture-Specific Configurations. Oxford; New York: Oxford University Press.

WooordHunt. (2019). Retrieved from https://wooordhunt.ru/

Zhang, Ch., \& Turner, M. (2019). Technology. Electric Car Sales Fall for First Time After China Cuts Subsidy. Bloomberg News. 03.09.2019. Retrieved from https://www.bloomberg.com/news/articles/2019-0903/electric-car-sales-fall-for-first-time-after-china-cuts-subsidy

Zheltukhina, M. R., \& Malygina, L. E. (2019). Principles of game AR technologies: gamification and television promo discourse. Cognitive researches of language, XXXVI. Understanding. Interpretation. Cognitive modeling, 371-378.

Zheltukhina, M. R., Bondareva, N. V., Zelenskaya, L. L., Anikeeva, I. G., Malygina, L. E., \& Chistyakov, A. V. (2019). Media Promotion Role of Economic Vocabulary: Specific Features and Functions in Presentation and Advertisement. Online Journal of Communication and Media Technologies, 9(2), e201907. https://doi.org/10.29333/ojcmt/5733
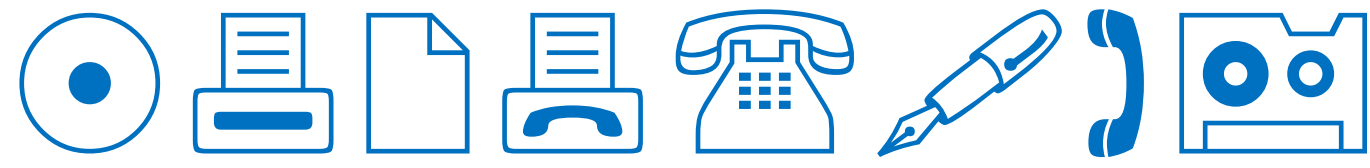